Bull. Fac. Agric., Cairo Univ., 70:43-52 (2019).

\title{
SPATIAL DISTRIBUTION OF SOIL CALCIUM CARBONATE, SALINITY, PH, SOIL TEXTURE AND ORGANIC MATTER CONTENT IN YOUSSEF EL-SEDIK DISTRICT AREA, FAYOUM GOVERNORATE, EGYPT
}

(Received: 18.2.2019)

\author{
By \\ M. Abd El-Gawad, A. M. Ibrahim, A. A. A. Abdel- Hafeez and Amany A. Ahmed \\ Department of Soils and Water, Faculty of Agriculture, Fayoum University, Fayoum, Egypt
}

\begin{abstract}
Spatial distribution of soil salinity, alkalinity, calcium carbonate, organic matter and soil texture (grid system-log distance of $2 \mathrm{~km}$ ) was identified and mapped throughout Youssef El-Sedik District area, Fayoum Governorate, Egypt, using ARC- GIS format. It was found that the ECe ranged between 0.68 and $132 \mathrm{dSm}^{-1}$ and from 0.92 to $82 \mathrm{dSm}^{-1}$ within the upper $10 \mathrm{~cm}$ and the $(10-50 \mathrm{~cm})$ soil layers, respectively. The data showed that $91.23 \%$ and $78.97 \%$ of the study area within the upper $10 \mathrm{~cm}$ and the $(10-50 \mathrm{~cm})$ layers respectively have $\mathrm{ECe}>4 \mathrm{dSm}^{-1}$. About 47.62 and $30.39 \%$ of the district soils have ECe values $>10 \mathrm{dSm}^{-1}$ within the upper and subsurface layers, respectively, indicating that salt- affected soils are distributed throughout the study area. About $92.53 \%$ of soils were calcareous ( $>10 \% \mathrm{CaCO}_{3}$ equivalent) due to the nature of parent material from which soils of the study area are evolved. Soil pH more than 7.5 was found in about $46.69 \%$ and less than $1 \%$ of soils have $\mathrm{pH}$ values $>8.0$ with a greatest $\mathrm{pH}$ value of 8.2. The organic matter contents seldom exceeded $2 \%$ in Youssef El-Sedik soils. Several different soil texture classes were found, however $46.38 \%$ and $42.65 \%$ of the soils were of clay texture within the $(0-10 \mathrm{~cm})$ and $(10-50 \mathrm{~cm})$ layers, respectively.
\end{abstract}

Key words: calcium carbonate, salinity, soil texture, organic matter, Youssef El-Sedik, Fayoum.

\section{INTRODUCTION}

Fayoum Governorate, is a large depression in Egypt located about $90 \mathrm{~km}$ southwest of Cairo, between latitudes 2915 and $2930 \mathrm{~N}$ and longitudes 3015 and 3045 E. It occupies $6,068.7 \mathrm{~km}^{2}$ including two artificial lakes at Wadi El Rayan, in addition to the natural Lake Qaroun. The climate is arid with an annual average rainfall of $8 \mathrm{~mm}$, and some years of no rainfall at all, while in some cases as much as 44 $\mathrm{mm}$ rainfalls in 1 day (Walter 1950).

The Governorate includes six administrative Districts, namely, Fayoum, Tamia, Etsa, Sinnuris, Ebshway, and Youssef El-Sedik. The study land area throughout Yousef El- Sedik District is about $388.5 \mathrm{~km}^{2}$.

According to several researches (Hanna and Labib 1977; Shendi 1984) the Fayoum depression formation belongs to three groups of sediments of distinctly different origins: river Nile, lacustrine and desert sediments forming four terraces. The studies of Hammad et al. (1983) showed that the soils of Fayoum belong to three soil orders: Vertisols, Entisols, and
Aridisols. The soils are expected to face the problems of salinity, alkalinity, calcium carbonate and high water table all over the depression area with a variability in their extent and spatial distribution due to variations in soil topography, slope, quality and available amount of irrigation water, drainage system and nearness to Lake Qaroun.

Studies of Abd Elgawad et al. ( 2013) on Tamia $\left(344.4 \mathrm{~km}^{2}\right)$ and Fayoum $\left(425.2 \mathrm{~km}^{2}\right)$ Districts and those of Howaida (2016) on Sinnuris District showed the levels of soil calcium carbonate, salinity, alkalinity, organic matter and soil texture throughout the land area of the three Districts. Very little information are available in the literature concerning the levels and spatial distribution of such properties throughout Youssef El- Sedik District area. Therefore, it is necessary to generate basic soil information which are important for better soil management and land use for Youssef El-Sedik District.

The present work was designed to study the levels, extent and spatial distribution of soil 
salinity, alkalinity, calcium carbonate, organic matter, soil texture and $\mathrm{pH}$ throughout Youssef El -Sedik District area using ARC GIS format.

\section{MATERIALS AND METHODS}

Surface $(0-10 \mathrm{~cm})$ and subsurface $(10-50$ $\mathrm{cm})$ soil samples were collected during the years 2012 and 2013 from 69 sites representing Youssef El-Sedik District soils. Samples were collected using a grid system at a distance of 2 $\mathrm{km}$. Location of the investigated area is shown in (Fig.1). Sampling sites (Fig. 2) were identified using the global positioning system "Garmin GPS".

Soil samples were air-dried, gently ground to pass a 2-mm sieve and stored in plastic bottles. Soil samples were analyzed for the following characteristics: particle-size distribution by the adapted hydrometer method (ASTM No. 152H
Temp.) using sodium hexameta phosphatesodium carbonate as dispersing agents (Bouyoucos, 1962): Calcium carbonate content was measured using Sheibler's calcimeter as described by Houba et al. (1995) and $\mathrm{pH}$ in saturated soil paste using a $\mathrm{pH}$ meter. The electrical conductivity of soil saturation paste extract (ECe) was measured using a conductivity bridge as described by US Salinity Lab Staff (1954). Organic matter content was determined using Walkley and Black method (Jackson 1979).

\subsection{Mapping}

Levels of the studied soil characteristics were classified into different categories (ranges), their geographical distribution throughout the whole area of Youssef El-Sedik District were identified and mapped using the interpolation capabilities of ARC GIS software to produce the different soil maps of each tested component.

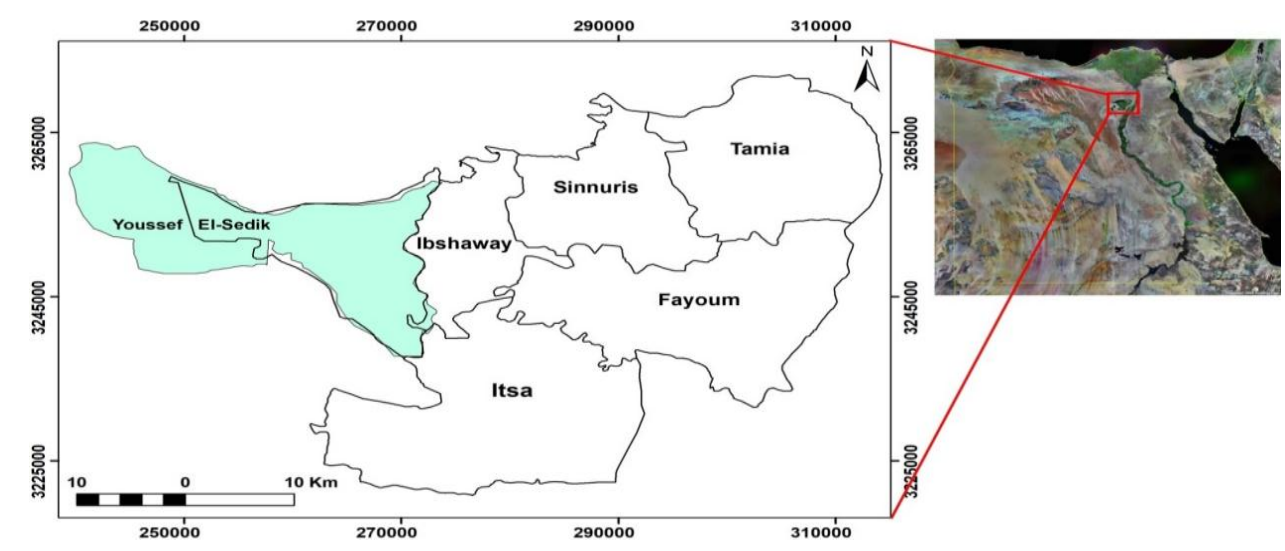

Fig. (1): Location of the investigated area (Youssef El-Sedik District) within Fayoum Governorate, Egypt.

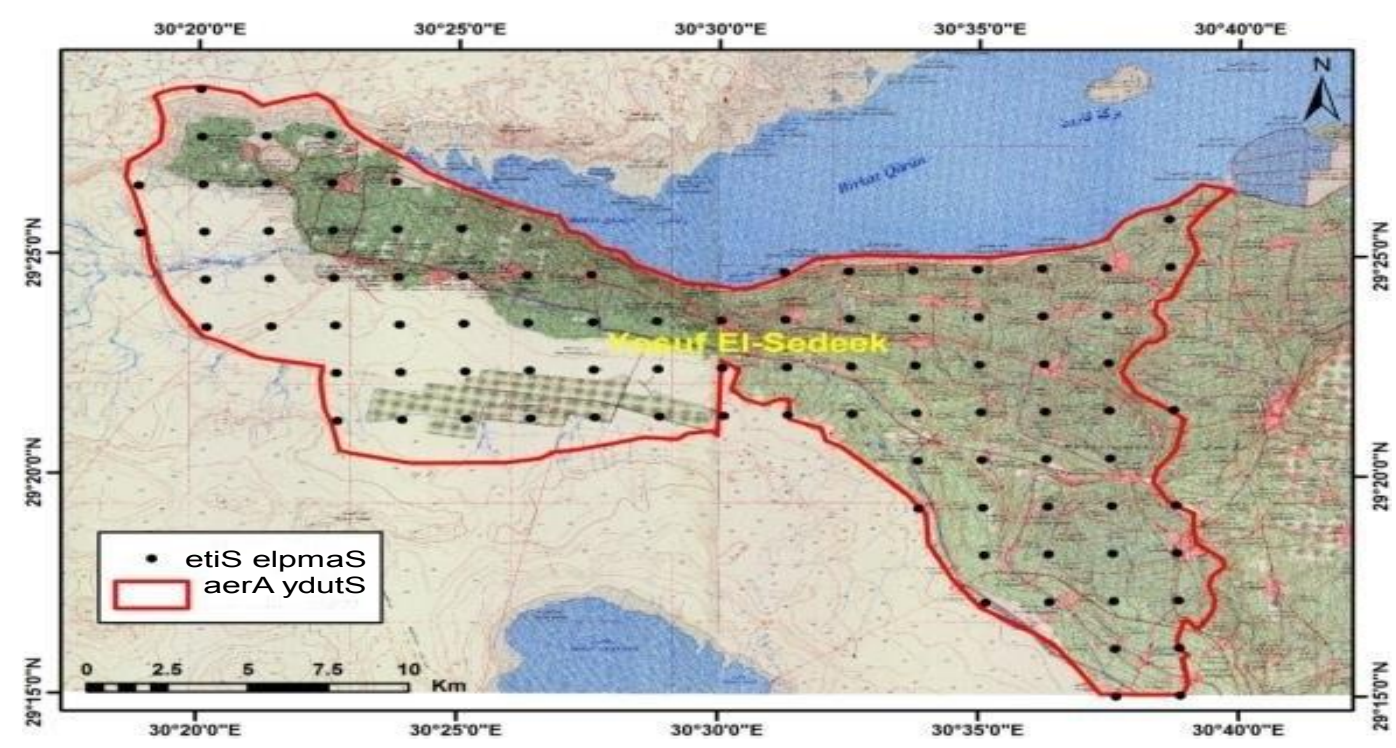

Fig. (2): Location of soil sampling sites throughout Yousef El-Sedik District area. 


\section{RESULTS AND DISCUSSION}

\subsection{Soil Salinity}

The levels of ECe values in the soils of Youssef El-Sedik District area are given in Table (1). Soil salinity maps are shown in Fig. (3and4). It could be observed from the data that the soils suffer soil salinization.

The data showed that the levels of ECe within the upper $10 \mathrm{~cm}$ layer ranged between $0.68 \mathrm{dSm}^{-1}$ and $132 \mathrm{dSm}^{-1}$ with a mean value of $10.81 \mathrm{dSm}^{-1}$, while ECe values for the $(10-50$ $\mathrm{cm}$ ) soil layer ranged between 0.92 and $82 \mathrm{dSm}^{-1}$ with a mean of $7.33 \mathrm{dSm}^{-1}$. It was found that the salinity level (ECe $>4 \mathrm{dSm}^{-1}$ ) exist in 91.23 and $78.97 \%$ of the District within the upper $10 \mathrm{~cm}$ and the $10-50 \mathrm{~cm}$ layers, respectively. About 47.62 and $30.39 \%$ of the study area have ECe values $>10 \mathrm{dSm}^{-1}$ in the upper and subsurface layers respectively.

The mean of ECe values within the upper 10 $\mathrm{cm}$ and the $10-50 \mathrm{~cm}$ soil layers indicated that the greatest ECe value and general mean were greater in the upper $10 \mathrm{~cm}$ in comparison with those of the subsurface one. Such accumulation of salts within soil surface could be due to the upward translocation of ground water and high evaporation rate under the hot arid climate of the study area.

The greatest soil salinity levels in terms of $\mathrm{ECe}$ values were found in scattered sites throughout the District area with no evidence for significant direct effect of the very high salinity of Lake Qaroun on soil salinity, emphasizing the influence of topography, high water table, and parent material, poor drainage and management on salinization in Youssef El-Sedik District area.

Effective control of soil salinization in the study area is impractical due to limited availability of Nile water and the limited extension of using mixed water (agriculture drainage with Nile water) to irrigate wide areas. However, salt affected areas in the District could be managed through soil improvement by appropriate land use, suitable agricultural practices and management, efficient drainage and irrigation systems, selection of salt-tolerant plant species based on salinity problem, and soil management.

\subsection{Soil pH}

The data presented in Table (2) indicated that soil $\mathrm{pH}$ in the upper layer $(0-10 \mathrm{~cm})$ ranged between 7.00 and 8.13 . While $\mathrm{pH}$ values of the subsurface layer $(10-50 \mathrm{~cm})$ ranged between 7.00 and 8.2. the data indicated the absence of sodic alkaline soils (of $\mathrm{pH} \geq 8.5$ ) within the upper $50 \mathrm{~cm}$ throughout the District area. The data also indicated that the $\mathrm{pH}$ values of more than $99 \%$ of Youssef El-Sedik District soils ranged between $7-8$ within both the upper 10 $\mathrm{cm}$ and the $10-50 \mathrm{~cm}$ layers. This could be due to the presence of $\mathrm{CaCO}_{3}$ at high levels in Youssef El-Sedik District lands. More than $92 \%$ and about $88 \%$ of the District soils have more than $10 \%$ of $\mathrm{CaCO}_{3}$ equivalent within the upper $10 \mathrm{~cm}$ and the $10-50 \mathrm{~cm}$ layers, respectively.

The spatial distribution of soil $\mathrm{pH}$ levels within the two studied depths in the different parts of Youssef El-Sedik District are shown in Fig. (5 and 6). Slight differences, with no trend were observed between the upper and the subsurface soil layers in their $\mathrm{pH}$ values.

\subsection{Organic matter content in soils}

The data in Table (3) and Figs. (7 and 8) show that soil organic matter contents of the upper $10 \mathrm{~cm}$ ranged between 0.26 and $2.27 \%$ with a mean of $1.24 \%$. The organic matter contents ranged between 0.06 and $2.19 \%$ with a mean of $1.36 \%$ within the subsurface soil layer $10-50 \mathrm{~cm}$.

The data indicated that the organic matter contents are generally higher in the upper soil layer 0-10 cm than those of the $10-50 \mathrm{~cm}$ layer.

Data of the present work emphasized the poorness of Youssef El-Sedik District soils in their organic matter content and their need to sufficient yearly applications of organic fertilizers and biofertilizers in order to improve soil physical, chemical properties and fertility status that will ultimate increase crop production.

\subsection{Calcium carbonate content in soils}

The data in Table (4) showed that calcium carbonate contents within the upper soil layer 0 $-10 \mathrm{~cm}$ ranged between 3.24 and 81.38 with an average of $15.04 \%$ and ranged between 3.57 and 51.04 with an average of $14.02 \%$ in subsoil layer $10-50 \mathrm{~cm}$.

More than $91 \%$ and about $87.75 \%$ of soils of study area had more than $10 \% \mathrm{CaCO}_{3}$ within the upper $10 \mathrm{~cm}$ and the $10-50 \mathrm{~cm}$ soil layers, Respectively (Table (4) and Figs. 9 and 10). Such high soil calcicity could be due to the calcic nature of the parent material from which soils of the study area are evolved.

\section{5.soil texture}

The distribution of clay contents in Youssef El-Sedik District area is presented in Figs. (11, 12) and Table (5). About $68.12 \%$ of the studied soils contain $\geq 30 \%$ clay within the upper $10 \mathrm{~cm}$; however $64.71 \%$ of soils contain $\geq 30 \%$ clay 
Table (1): Levels of ECe values in the soils of Youssef El-Sedik District area.

\begin{tabular}{|c|c|c|c|}
\hline Soil depth $(\mathrm{cm})$ & $\mathrm{ECe}\left(\mathrm{dSm}^{-1}\right)$ & Area (ha) & \% of District area \\
\hline \multirow{5}{*}{$0-10$} & $0.68-4.00$ & 3173 & 8.77 \\
\cline { 2 - 4 } & $4.01-10.00$ & 15775 & 43.61 \\
\cline { 2 - 4 } & $10.01-20.00$ & 13951 & 38.57 \\
\cline { 2 - 4 } & $20.01-40.00$ & 2399 & 6.63 \\
\cline { 2 - 4 } & $40.01-80.00$ & 739 & 2.04 \\
\cline { 2 - 4 } & $80.01-100.00$ & 86 & 0.24 \\
\hline \multirow{5}{*}{ mean } & $100.01-132.00$ & 52 & 0.14 \\
\hline \multirow{5}{*}{$10-50$} & 10.81 & & \\
\cline { 2 - 4 } & $0.92-4.00$ & 7607 & 21.03 \\
\cline { 2 - 4 } & $4.01-10.00$ & 17574 & 48.58 \\
\hline & $10.01-20.00$ & 9522 & 26.32 \\
\hline & $20.01-40.00$ & 1219 & 3.37 \\
\hline & $40.01-80.00$ & 249 & 0.69 \\
\hline & $80.01-82.00$ & 4 & 0.01 \\
\hline
\end{tabular}

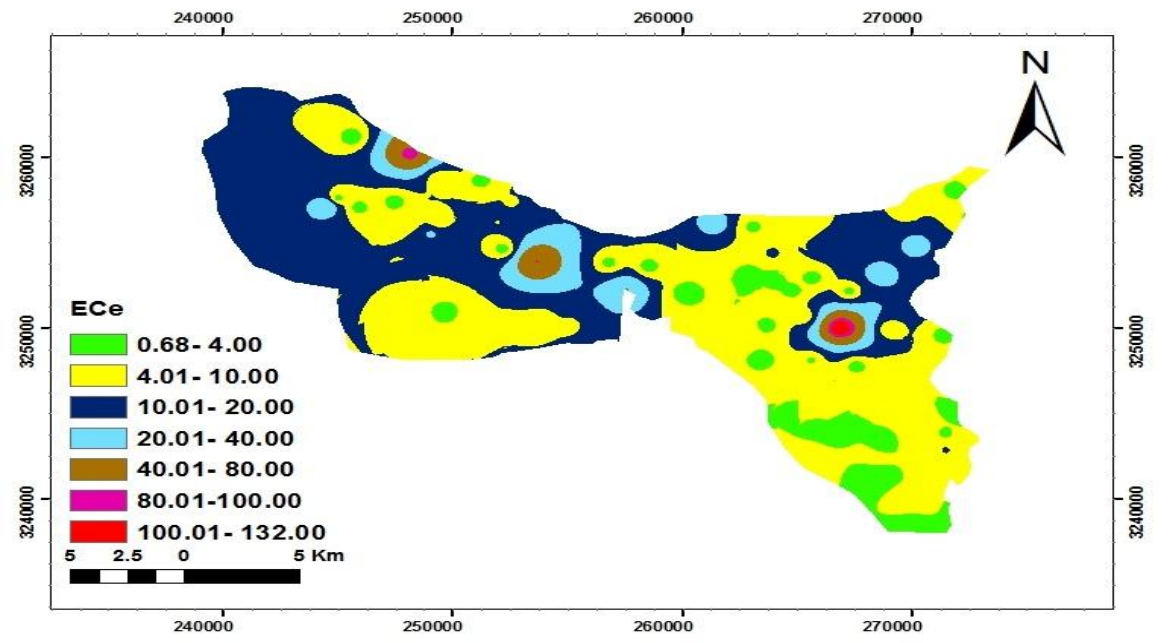

Fig. (3): Spatial distribution of the soil salinity in terms of ECe values (dSm-1) throughout Youssef El-Sedik District area (soil depth 0-10 cm).

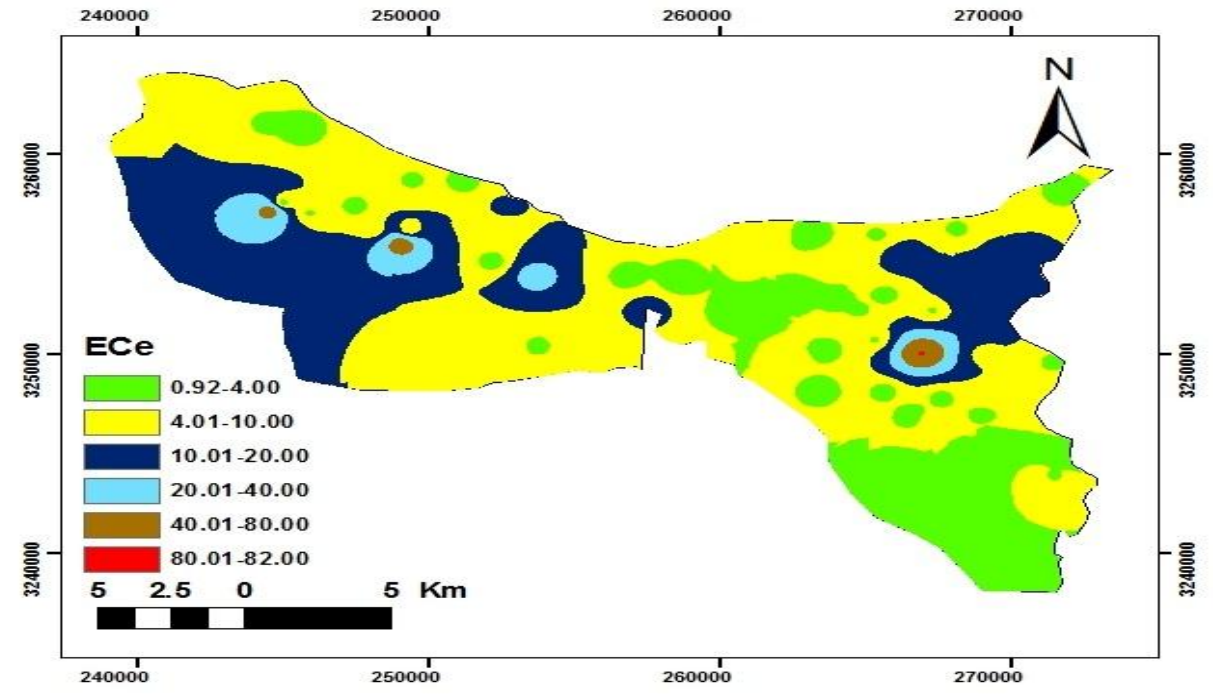

Fig. (4): Spatial distribution of soil salinity in terms of ECe values (dSm-1) throughout Youssef El-Sedik District area (soil depth $10-50 \mathrm{~cm}$ ). 
Table (2): Levels of pH values in the soils of Youssef El-Sedik District area.

\begin{tabular}{|c|c|c|c|}
\hline Soil depth $(\mathrm{cm})$ & Soil pH & Area (ha) & \% of District area \\
\hline \multirow{3}{*}{$0-10$} & $7.00-7.50$ & 19287 & 53.32 \\
\cline { 2 - 4 } & $7.51-8.00$ & 16838 & 46.55 \\
\cline { 2 - 4 } & $8.01-8.13$ & 51 & 0.13 \\
\hline \multirow{3}{*}{$10-50$} & $7.00-7.50$ & 11487 & 31.75 \\
\cline { 2 - 4 } & $7.51-8.00$ & 24572 & 67.92 \\
\cline { 2 - 4 } & $8.01-8.2$ & 116 & 0.33 \\
\hline
\end{tabular}

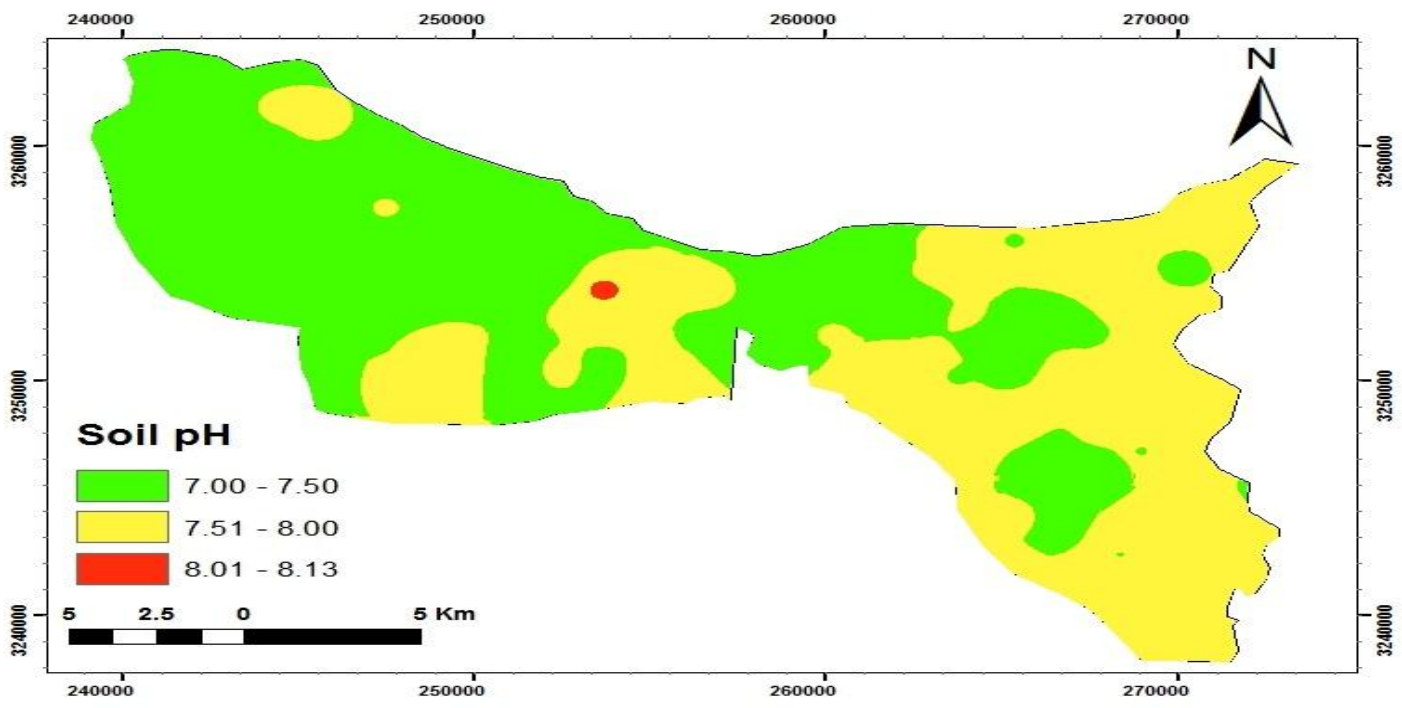

Fig .(5): Spatial distribution of the soil pH levels throughout Youssef El-Sedik District area (soil depth 0-10 cm).

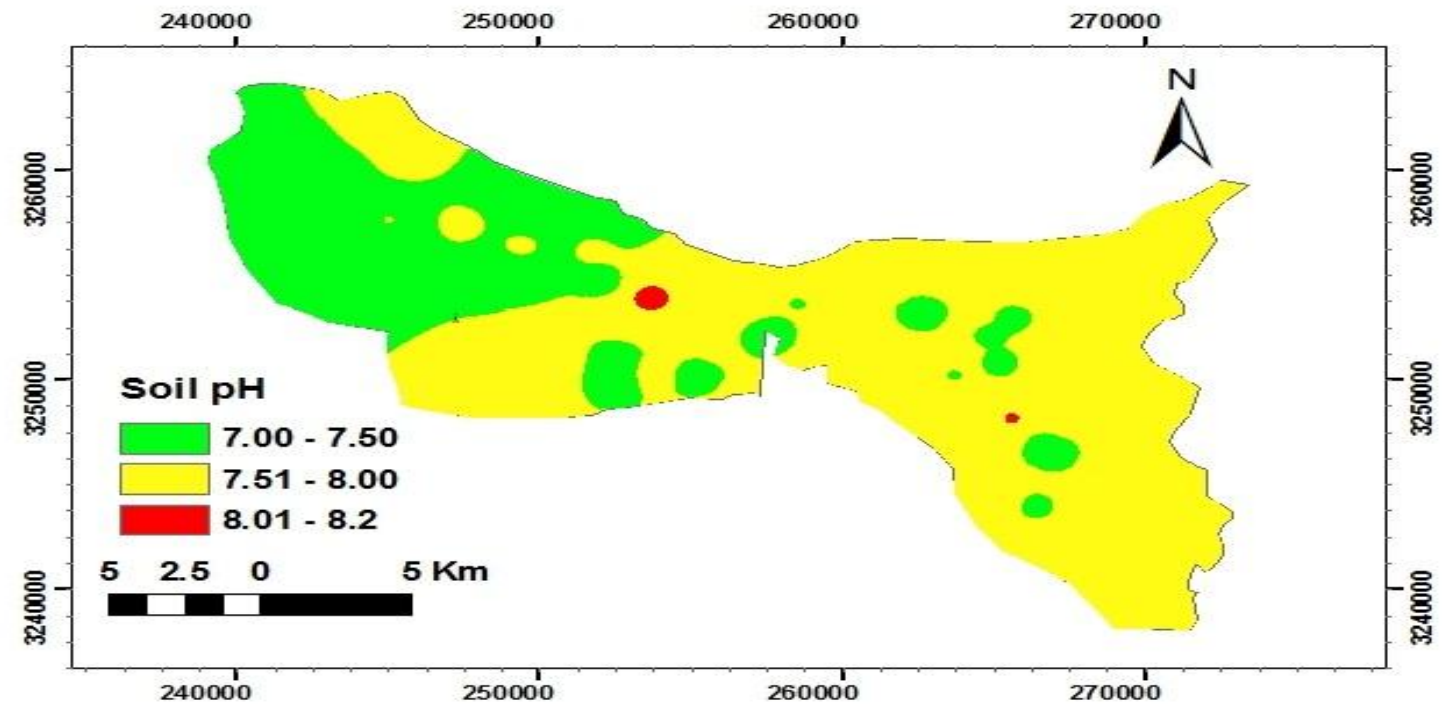

Fig .(6): Spatial distribution of the soil pH levels throughout Youssef El-Sedik District area (soil depth $10-50 \mathrm{~cm})$. 


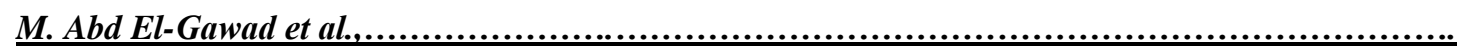

Table (3): Levels of organic matter content in the soils of Youssef El-Sedik District area.

\begin{tabular}{|c|c|c|c|}
\hline Soil depth (cm) & Soil organic matter \% & Area (ha) & \% of District area \\
\hline \multirow{4}{*}{$0-10$} & $0.26-0.50$ & 204 & 0.57 \\
\cline { 2 - 4 } & $0.51-1.00$ & 12224 & 33.79 \\
\cline { 2 - 4 } & $1.01-1.50$ & 17342 & 47.94 \\
\cline { 2 - 4 } & $1.51-2.00$ & 6275 & 17.35 \\
\hline \multirow{5}{*}{ mean } & $2.01-2.27$ & 130 & 0.35 \\
\hline \multirow{5}{*}{$10-50$} & 1.24 & 491 & 1.36 \\
\cline { 2 - 4 } & $0.06-0.50$ & 12126 & 33.51 \\
\cline { 2 - 4 } & $0.51-1.00$ & 21642 & 59.83 \\
\cline { 2 - 4 } & $1.01-1.50$ & 1888 & 5.22 \\
\cline { 2 - 4 } & $1.51-2.00$ & 28 & 0.08 \\
\hline \multirow{2}{*}{ mean } & $2.01-2.19$ & & \\
\hline
\end{tabular}

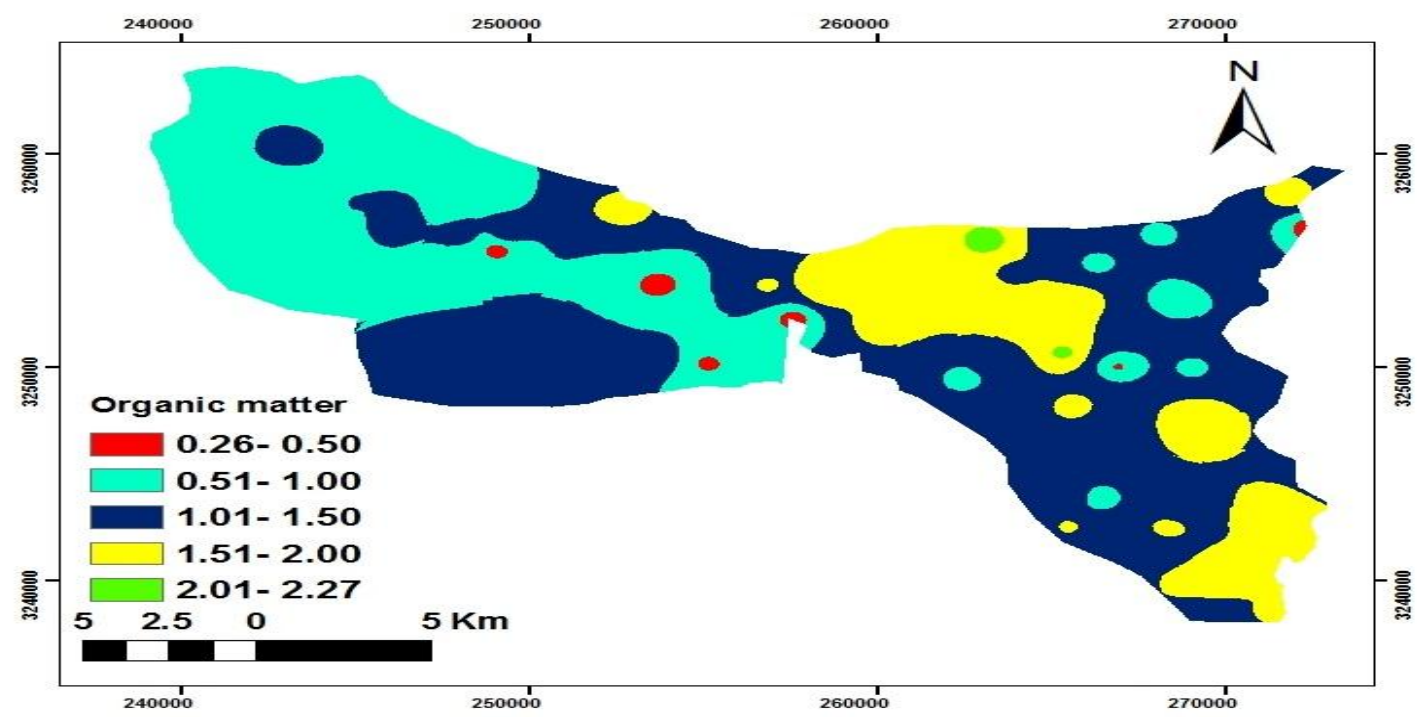

Fig. (7): Spatial distribution of the soil Organic matter contents (\%) throughout Youssef El-Sedik District area (soil depth 0-10 cm).

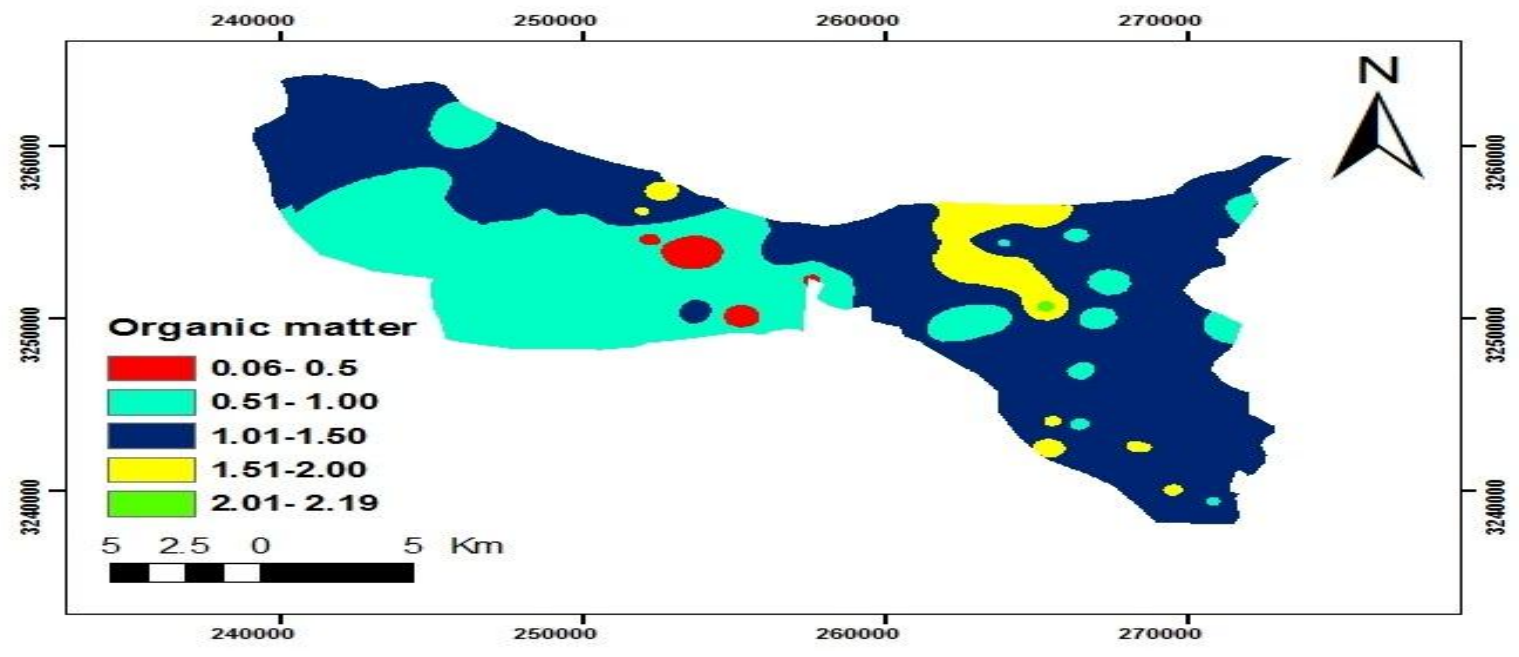

Fig. (8): Spatial distribution of the soil organic matter contents (\%) throughout Youssef El-Sedik District area (soil depth 10-50) 
Table (4): Levels of calcium carbonate content in the soils of Youssef El-Sedik District area.

\begin{tabular}{|c|c|c|c|}
\hline Soil depth (cm) & $\mathbf{C a C O}_{3}$ equivalent \% & Area (ha) & \% of District area \\
\hline \multirow{4}{*}{$0-10$} & $3.24-4.9$ & 47 & 0.13 \\
\cline { 2 - 4 } & $5.00-10.00$ & 2656 & 7.34 \\
\cline { 2 - 4 } & $10.01-20.00$ & 27637 & 76.40 \\
\cline { 2 - 4 } & $20.01-40.00$ & 5462 & 15.10 \\
\cline { 2 - 4 } & $40.01-60.00$ & 261 & 0.72 \\
\hline \multirow{3}{*}{ mean } & $60.01-81.38$ & 113 & 0.31 \\
\hline \multirow{3}{*}{$10-50$} & 15.04 & 12 & 0.04 \\
\cline { 2 - 4 } & $3.57-4.90$ & 4429 & 12.24 \\
\cline { 2 - 4 } & $5.00-10.00$ & 24821 & 68.61 \\
\cline { 2 - 4 } & $10.01-20.00$ & 6739 & 18.63 \\
\cline { 2 - 4 } & $20.01-40.00$ & 174 & 0.48 \\
\hline \multirow{2}{*}{ mean } & $40.01-51.04$ & & \\
\hline
\end{tabular}

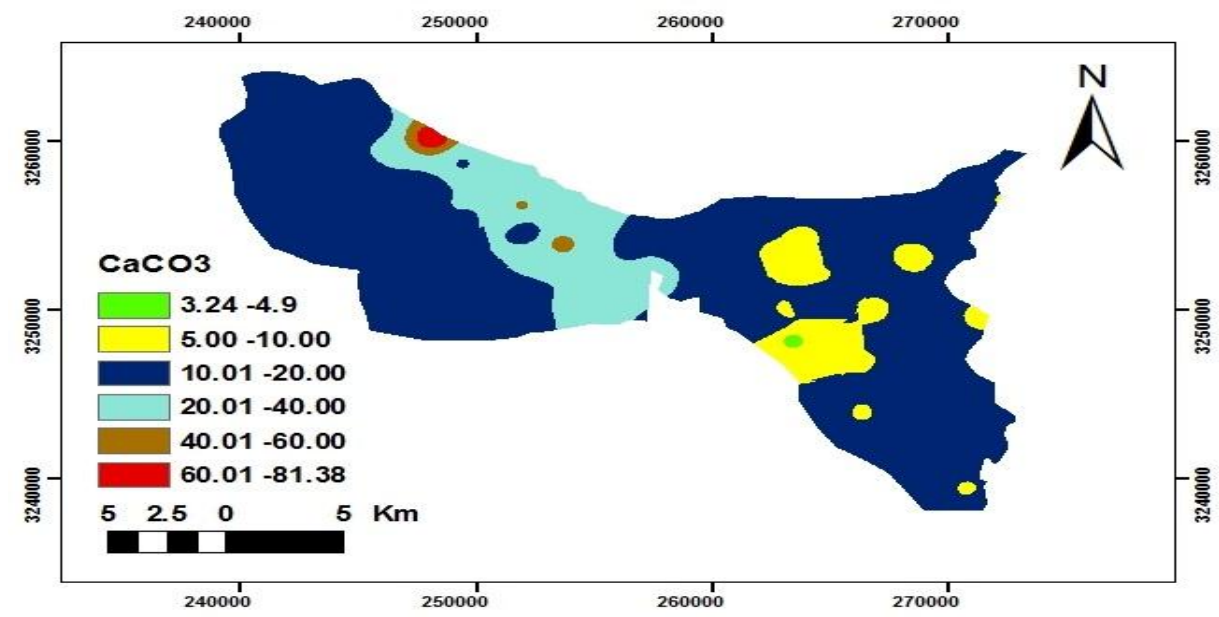

Fig. (9): Spatial distribution of calcium carbonate equivalents (\%) in the soils throughout Youssef ElSedik District area (soil depth 0-10 cm).

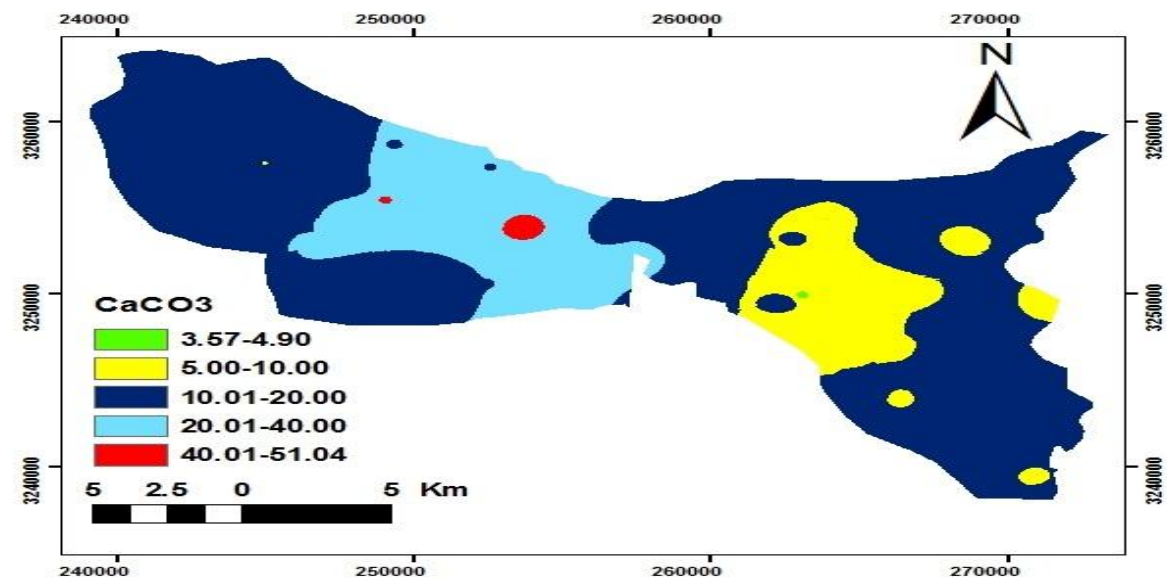

Fig. (10): Spatial distribution of calcium carbonate equivalents (\%) in the soils throughout Youssef ElSedik District area (soil depth 10-50 cm). 


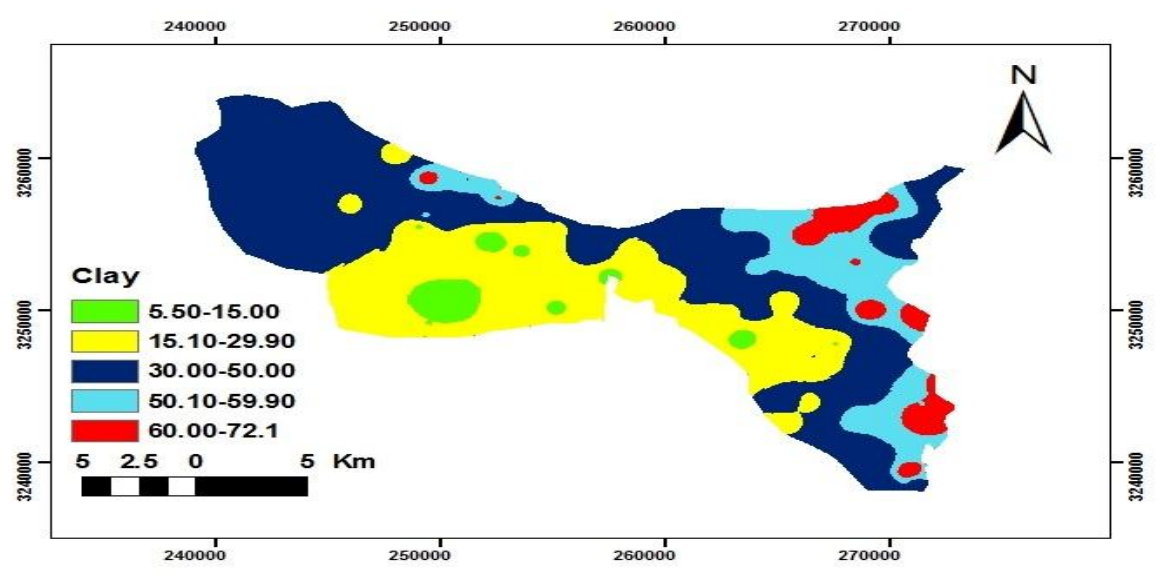

Fig. (11): Spatial distribution of clay contents (\%) in the soils throughout Youssef El-Sedik District area (soil depth 0-10 cm).

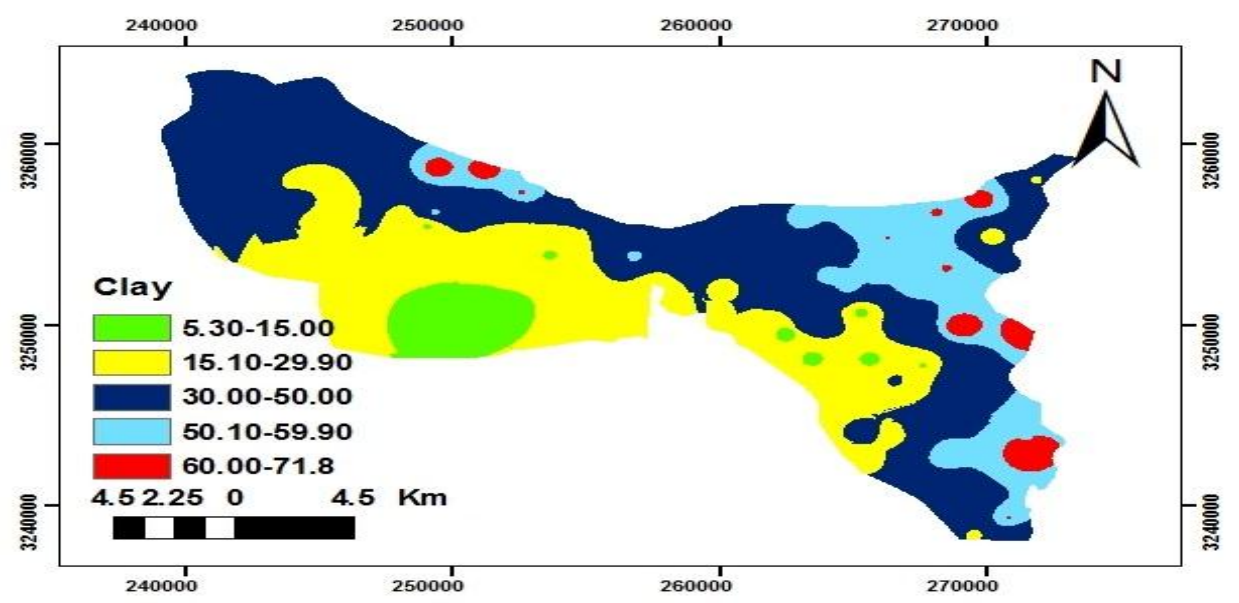

Fig. (12): Spatial distribution of clay contents (\%) in the soils throughout Youssef El-Sedik District area (soil depth 10-50 cm).

Table (5): Levels of clay content in the soils throughout Youssef El-Sedik District area.

\begin{tabular}{|c|c|c|c|}
\hline Soil depth (cm) & Clay, \% & Area (ha) & \% of District area \\
\hline \multirow{4}{*}{$0-10$} & $5.50-15.00$ & 1199 & 3.30 \\
\cline { 2 - 4 } & $15.10-29.90$ & 10718 & 29.63 \\
\cline { 2 - 4 } & $30.00-50.00$ & 17605 & 48.67 \\
\cline { 2 - 4 } & $50.01-59.00$ & 5002 & 13.83 \\
\hline \multirow{3}{*}{ mean } & $60.00-72.10$ & 1651 & 4.57 \\
\hline \multirow{3}{*}{$10-50$} & 39.53 & & 5.75 \\
\cline { 2 - 4 } & $5.30-15.00$ & 2083 & 30.73 \\
\cline { 2 - 4 } & $15.10-29.90$ & 11115 & 46.43 \\
\cline { 2 - 4 } & $30.00-50.00$ & 16797 & 14.61 \\
\cline { 2 - 4 } & $50.10-59.90$ & 5284 & 2.48 \\
\hline
\end{tabular}

within the $10-50 \mathrm{~cm}$ soil layer. About $49.28 \%$ and $42.65 \%$ of the studied soils were found to contain $\geq 40 \%$ clay within the upper $10 \mathrm{~cm}$ and
$10-50 \mathrm{~cm}$ layers, respectively. Very little differences were observed between the upper 10 $\mathrm{cm}$ and the $10-50 \mathrm{~cm}$ soil layers in their mean 
values, maximum and minimum contents of clay.

The data in Table (6) showed that soil texture classes of the upper $10 \mathrm{~cm}$ were clay in $46.38 \%$ of the studied soils, $5.8 \%$ sandy clay, $10.14 \%$ clay loam, $18.84 \%$ sandy clay loam, $1.45 \%$ loamy, $13.04 \%$ sandy loam and $4.35 \%$ loamy sand. Soil texture classes of the subsurface $10-50 \mathrm{~cm}$ layers were clay in about $42.65 \%, 1.47 \%$ silty clay, $7.53 \%$ sandy clay, $8.83 \%$ clay loam, $20.59 \%$ sandy clay loam, $1.47 \%$ loamy, $1.47 \%$ silt loam, $10.29 \%$ sandy loam and $5.88 \%$ of the studied soils loamy sand. salinity, alkalinity, and calcicity within Fayoum and Tamia Districts, Fayoum Governorate, Egypt. Developments in Soil Assessment and Reclamation. Springer Science. DOI 10.1007/978-94-007-56847. 14: $219-236$

Bouyoucos G. J. (1962). Hydrometer method improved for making particle-size analysis of soils. Agron. J., 53: 464-465

Hammad M.A., Abo El-Einane S. and Abed F. (1983). Pedological studies on the Fayoum area, Egypt. I. landscape and soil morphology. Egypt. J. Soil Sci. 23(2):99-

Table (6): Distribution of the soil texture classes throughout Youssef El-Sedik District area.

\begin{tabular}{|c|c|c|}
\hline Soil depth $(\mathrm{cm})$ & Soil texture class & \% of District soils \\
\hline \multirow{4}{*}{$(0-10)$} & Clay & $46.38 \%$ \\
\cline { 2 - 3 } & Sandy clay & $5.80 \%$ \\
\cline { 2 - 3 } & Clay loam & $10.14 \%$ \\
\cline { 2 - 3 } & Sandy clay loam & $18.84 \%$ \\
\cline { 2 - 3 } & Loam & $1.45 \%$ \\
\cline { 2 - 3 } & Sandy loam & $13.04 \%$ \\
\hline \multirow{4}{*}{$(10-50)$} & Loamy sand & $4.35 \%$ \\
\cline { 2 - 3 } & Clay & $42.65 \%$ \\
\cline { 2 - 3 } & Silty clay & $1.47 \%$ \\
\cline { 2 - 3 } & Sandy clay & $7.35 \%$ \\
\cline { 2 - 3 } & Clay loam & $8.83 \%$ \\
\cline { 2 - 3 } & Sandy clay loam & $20.59 \%$ \\
\cline { 2 - 3 } & Loam & $1.47 \%$ \\
\cline { 2 - 3 } & Silty loam & $1.47 \%$ \\
\cline { 2 - 3 } & Sandy loam & $10.29 \%$ \\
\hline
\end{tabular}

It could be concluded from the data of the present work that the soils of Youssef El-Sedik District suffer problems associated with soil salinity, high calcium carbonate, poorness in organic matter content. The degree, extent and spatial distribution of such problems throughout the District area were well defined. These problems, in addition to those of irrigation water deficiency and quality, hot weather and aridity are facing decision makers.

\section{REFERENCES}

Abd Elgawad M., Shendi M. M., Dalia M. S., Abdurrahman H. A. and Asmaa M. A. (2013). Geographical distribution of soil
114

Hanna F.S. and Labib F. (1977). Pedological studies on the Fayoum area, Egypt. I. landscape and soil morphology. Egypt $\mathrm{J}$. Soil Sci. 23(2) :99-114.

Houba V.J.G., Van der Lee J.J. and Novozamsky I.(1995). Soil analysis procedures: soil and plant analysis, part 5B. Department of Soil Science and Plant Nutrition, Wageningen Agriculture University, Wageningen, the Nether lands.

Howaida S. A. (2016). Status of cadmium, nickel, and lead in soils, water resources and applied chemical fertilizers at Sinnuris District, Fayoum Governorate, 
M.Sc. Thesis, Faculty of Agriculture Fayoum Univ., Fayoum , Egypt.

Jackson M. L. (1979). Soil Chemical Analysis. Prentice-Hall, Inc., Upper Saddle River.

Shendi M. M. (1984). Pedological studies on soils adjacent to Qaroun Lake, Fayoum Governorate Egypt. M.Sc. Thesis, Faculty of Agriculture, Cairo University, Egypt.
US Salinity Lab Staff (1954). Diagnosis and improvement of saline and alkali soils. US Department of Agriculture (USDA), Handbook no. 60, $2^{\text {nd }}$ edn, US Salinity Lab Staff, Washington, DC,USA.

Walter H. (1950). Die vegetation Der: in Okoogischer veb. Gustuy Fisher Verlogjenn. Soils Fert. 32: 2714.

\section{التوزيع الجغرافى لكريونات الكالسيوم و للملحية والرقم الهيدروجينى والقوام ومحتوى التربة من المادة العضوية فى

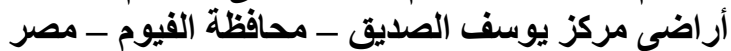

محمود عبد الجواد محمد ـ عبد العاطى محمد أبراهيم - عبد الناصر أمين أحمد عبدالحفيظ، ـ أماني عبد الناصر أحمد

$$
\text { قسم الأراضي و المياه - كلية الزر اعة - جامعة الفيوم ـالفيوم - مصر. }
$$

\section{ملخص}

أُستخدمت نظم المعلومات الجغر افية ARC-GIS Format في دراسة ورسم خرائط ملونة للتوزيع الجغرافى الجي

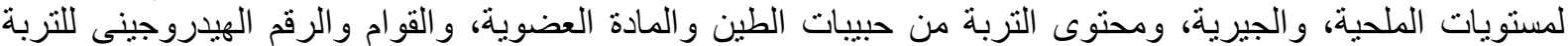

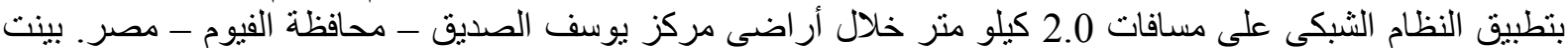

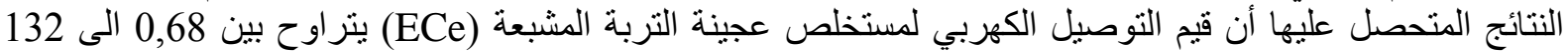

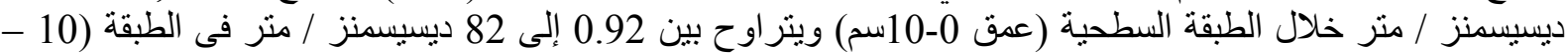

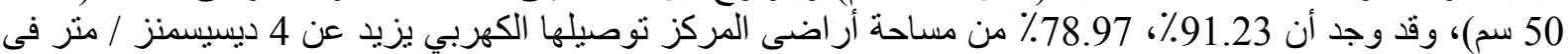

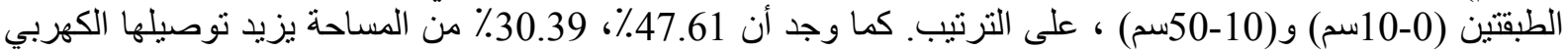

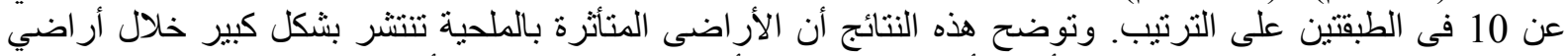

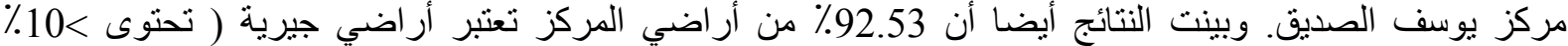

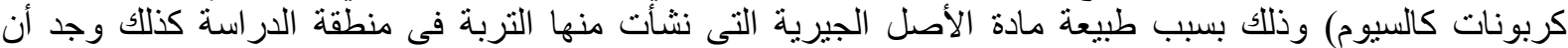

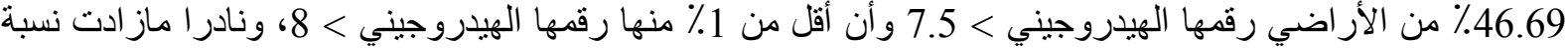

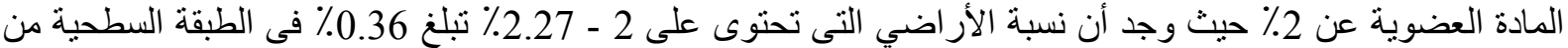

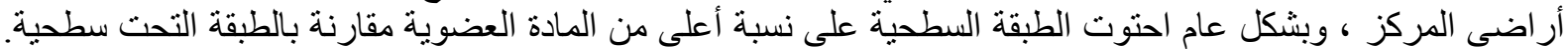
وتنوعت رتب قوام التربة الا أن نسبة الأر اضى ذات القو ام الطينى بلغت

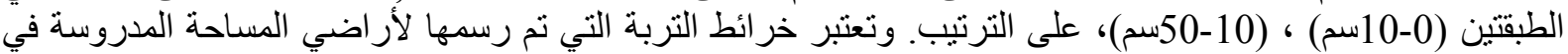

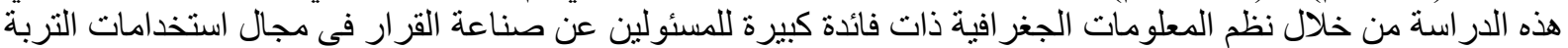
المناسبة وحفظ الأر اضى و ادارتها وكذلك كمعلومات اساسية للارسين و الباحثين لأجر اء البحوث المستقبلية فى منطقة هذه 